УДК 621.444 .5

\title{
АНАЛІЗ ПОЛІТРОПНОГО СУБАТМОСФЕРНОГО ТЕРМОДИНАМІЧНОГО ЦИКЛА ГТУ 3 ТЕПЛОМАСООБМІННИМ АПАРАТОМ МАЙСОЦЕНКА
}

\author{
Халатов А.А. ${ }^{1,2}$, академік НАН України, Сєвєрін С.Д. ${ }^{1}$, канд. тех. наук, Кочура Ю.П. ${ }^{2}$, \\ Бродецький П.І. ${ }^{3}$
}

${ }^{1}$ Інститут технічної теплофізики НАН Украӥни, вул. Желябова, 2а, Київ, 03680, Украӥна

${ }^{2}$ Національний технічний університет Украӥни «Київський політехнічний інститут», просп. Перемоги, 37, Київ, 03056, Украӥна

${ }^{3}$ Public Benefit Corporation, Los Angeles, USA

Виконано термодинамічний аналіз політропного субатмосферного цикла ГТУ $з$ тепломасообмінним апаратом Майсоцека. На основі цього аналізу отримано техніко-економічні характеристики політропного цикла й проведено їх порівняння 3 показниками адіабатного цикла. Показано, що для температури паро-повітряної суміші перед турбіною $340{ }^{\circ} \mathrm{C}$, термічний ККД політропного цикла зменшується відносно адіабатного цикла на $12,4 \ldots 5,2 \%$ при зміні температури повітря за сонячним нагрівачем від 40 до $90{ }^{\circ} \mathrm{C}$. У політропному циклі термічний ККД досягає $72 \%$.

Бібл. 3, табл. 1, рис. 4.
Выполнено термодинамический анализ политропного субатмосферного цикла ГТУ с тепломассообменным аппаратом Майсоценка. На основе этого анализа получены технико-экономические характеристики политропного цикла и проведено их сравнение с показателями адиабатного цикла. Показано, что для температуры паровоздушной смеси перед турбиной $340{ }^{\circ} \mathrm{C}$, термический КПД политропного цикла уменьшается по сравнению с адиабатным циклом на $12,4 \ldots 5,2$ \% при изменении температуры воздуха за солнечным нагревателем от 40 до $90{ }^{\circ} \mathrm{C}$. В политропном цикле термический КПД достигает $72 \%$.
The thermodynamics analysis of polytropic subatmospheric cycle of gas turbine unit (GTU) with Maisotsenko heat and mass exchanger is executed. Being based on this analysis was obtained technical and economic characteristics of polytropic cycle and conducted their comparing with characteristics of adiabatic cycle. It is shown that for the temperature of steamair mixture at turbine inlet of $340^{\circ} \mathrm{C}$ the thermal efficiency of polytropic cycle decreases in relation to an adiabatic cycle on $12,4 \ldots .5,2 \%$ at the change of air temperature after a sunny heater from 40 to $90^{\circ} \mathrm{C}$. The thermal efficiency of polytropic cycle is reached to 72 per cent.

Ключові слова: субатмосферний цикл Брайтона, цикл Майсоценка, регенерація теплоти, політропний процес, тепломасообмін.

$G$ - масові витрати, кг/с;

$T$ - температура, ${ }^{\circ} \mathrm{C}$;

$\eta$ - коефіцієнт корисної дії;

$\sigma-$ ступінь/міра регенерації теплоти.

\section{Індекси:}

air- повітря;

$e l$ - електричний;

\section{Bcmyn}

Практично усі сучасні газотурбінні двигуни та промислові газотурбінні установки працюють за прямим термодинамічним циклом Брайтона у діапазоні температур робочого тіла від $730{ }^{\circ} \mathrm{C}$ до $1650{ }^{\circ} \mathrm{C}$ перед турбіною та ступенем стиснення від 3 до 30. Проте, основним недоліком таких установок $є$ значна кількість невикористаної $t$ - термічний;

$w$ - вода.

\section{Скорочення:}

ГТУ - газотурбінна установка;

ККД - коефіцієнт корисної дії;

М-цикл - цикл Майсоценка.

теплової енергії, яка викидається в атмосферу без подальшого її використання. У зв'язку із цим, термічний ККД кращих на сьогоднішній день ГТУ не перевищує $40 \%$.

Пошук можливих шляхів підвищення термодинамічної ефективності привів до ідеї оберненого цикла Брайтона у якому термодинамічні процеси протікають у зворотньому нап- 
рямку [1]. Проте, така конфігурація оберненого цикла не отримала широкого практичного використання із-за різкого збільшення об'єму компресора і великих витрат енергії на його привід.

Ця проблема може бути вирішена завдяки комбінації оберненого цикла Брайтона із циклом Майсоценка, що відкриває принципову можливість у створенні газотурбінних установок 3 високими значеннями ККД, які значно перевищують ККД прямого цикла Брайтона. Така комбінація термодинамічних циклів була уперше розглянута в роботі [2]. Схема ГТУ представлена на рис. 1.

Важливою особливістю цього цикла $\epsilon$ можливість використання енергії довкілля у формі психрометричної енергії. Результати розрахунку, які представлені в роботі [2] показали, що в адіабатному субатмосферному циклі ГТУ 3 тепломасообмінним апаратом Майсоценка можуть досягатися високі значення електричного та термічного ККД на рівні $60 \%$ та $70 \%$ відповідно при відносно невисоких температурах паро-повітряного потоку перед турбіною до $340{ }^{\circ} \mathrm{C}$.

Проте, усі термодинамічні процеси за реальних умов є близькими до політропних, тобто такі, які враховують гідравлічні та енергетичні втрати. Будь-які втрати в свою чергу призводить до зменшення термодинамічної ефективності. Тому, метою даної роботи є визначення технікоекономічних характеристик політропного субатмосферного цикла ГТУ 3 тепломасообмінним апаратом Майсоценка та порівняння їх 3 характеристиками ідеального цикла.

\section{Вихідні дані для розрахунку}

Вихідні дані, які використовувалися при розрахунку наводяться нижче у міжнародній системі одиниць CI:

- газова постійна сухого повітря: 287 Дж/(кг·К);

- газова постійна повітря на виході із камери згорання: 289 Дж/(кг·К);

- газова постійна водяного пара: 461,5 Дж/(кг·К);

- питома ізобарна теплоємність водяного пара: 1875,69 Дж/(кг·К);

- питома теплота випаровування водяного пара: 2501 кДж/(кг·К);

- атмосферний тиск: 101,325 кПа;

- температура повітря на вході у сонячний нагрівач: $20^{\circ} \mathrm{C}$;

- відносна вологість атмосферного повітря: $20 \%$;

- вологовміст атмосферного повітря визначається за $\boldsymbol{d}-\boldsymbol{h}$ діаграмою Рамзіна-Мольє;

- температура повітря на виході із сонячного нагрівача $T_{2}: 40 \ldots 90{ }^{\circ} \mathrm{C}$ (варіюється);

- температура паро-повітряної суміші перед турбіною $T_{4}: 200$ i $340{ }^{\circ} \mathrm{C}$.

Характерні коефіцієнти та їх значення, які враховують політропну природу термодинамічних процесів наведено у таблиці 1. Значення цих коефіцієнтів відповідають сучасним вимогам до елементів ГТД.

У якості палива взято гас для якого стехіометричний коефіцієнт становить 15,67 (кг повітря/кг палива), а теплотворна здатність 4754 кДж/кг.

Таблиця 1. Коефіцієнти, які враховують ступінь політропності цикла

\begin{tabular}{|c|l|c|}
\hline № & \multicolumn{1}{|c|}{ Коефіціснт } & Значення \\
\hline 1 & Збереження загального тиску у сонячному нагрівачу & 0,92 \\
\hline 2 & Збереження загального тиску у вологих каналах апарата Майсоценка & 0,92 \\
\hline 3 & Збереження загального тиску у сухих каналах апарата Майсоценка & 0,92 \\
\hline 4 & Збереження загального тиску у камері згорання & 0,96 \\
\hline 5 & Збереження загального тиску у додатковому теплообміннику & 0,92 \\
\hline 6 & Повнота згорання палива & 0,9 \\
\hline 7 & Корисна дія турбіни & 0,9 \\
\hline 8 & Корисна дія компресора & 0,85 \\
\hline
\end{tabular}




\section{Програма розрахунку}

Розрахунки техніко-економічних характеристик політропного цикла, виконано за допомогою тієї ж комп'ютерної програми, що і для ідеального циклу [2].

Для визначення тиску насиченого водяного пара використовується апроксимаційна схема Кінона-Кейза (Keenan and Keyes), а для визначення вологовмісту насиченого повітря - апроксимаційна схема, яка отримана на основі табличних даних наведених у роботі [3].

Відносна похибка визначення вологовмісту в сухих каналах апарата Майсоценка складає $0,1 \%$. Вологовміст повітря у вологих каналах та каналах конденсації апарата Майсоценка визначається із кореляційних залежностей, які зв'язані з температурою та тиском робочого тіла у заданих точках цикла. Відносна похибка визначення температури робочого тіла у каналах конденсації М-цикла складає $1 \%$.

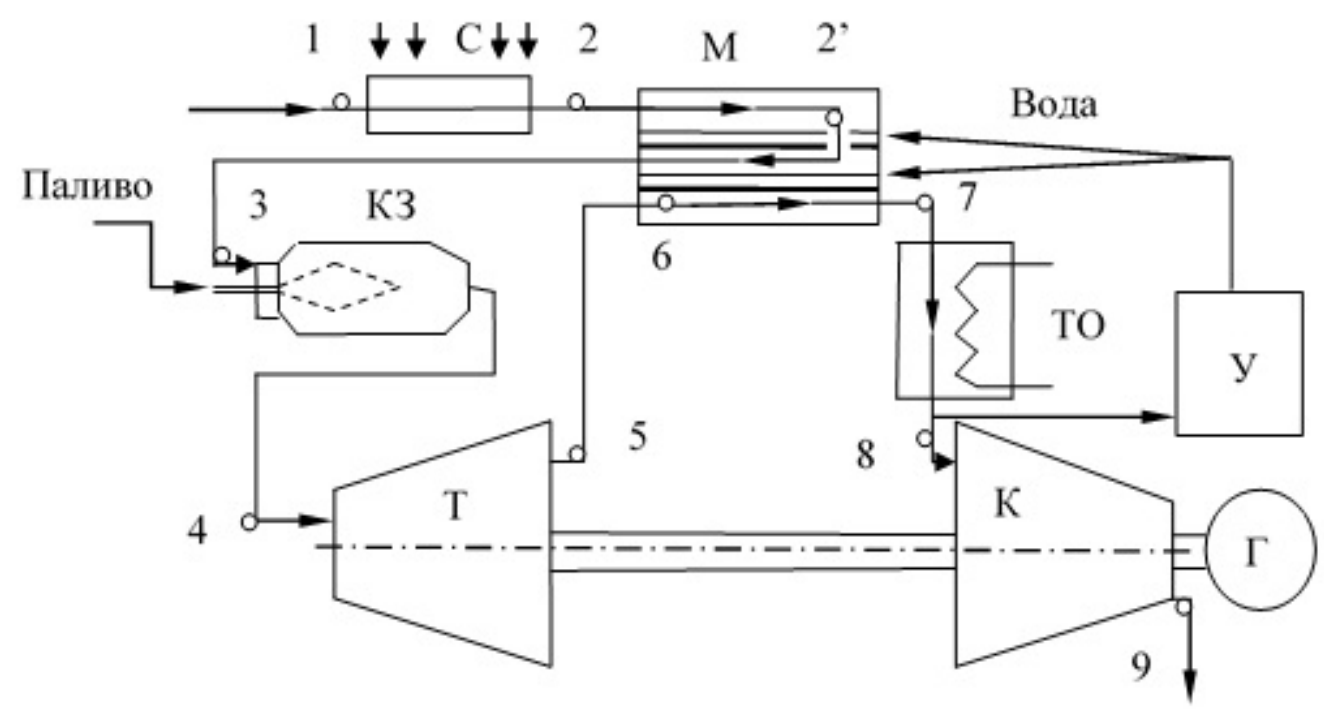

Рис. 1. Газотурбінна установка субатмосферного термодинамічного цикла 3 тепломасообмінним апаратом Майсоценка [2]:

C - сонячний нагрівач, М - апарат Майсоценка, К3 - камера згорання,

T- турбіна, ТО - додатковий теплообмінник, У-уловлювач льоду, К-компресор, $\Gamma$ - електрогенератор.

\section{Результати дослідження}

На рис. 2 наведено порівняльні залежності термічного ККД у адіабатному та політропному циклах від температури повітря на виході із сонячного нагрівача та температури паро-повітряної суміші перед турбіною. Як видно із цих залежностей у адіабатному і політропному циклах, збільшення температури паро-повітряної суміші перед турбіною та температури повітря за сонячним нагрівачем, призводить до зростання термічного ККД. По мірі збільшення температури повітря за сонячним нагрівачем, відмінність між значеннями термічного ККД у адіабатному та політропному циклах зменшується. Для температури повітря за сонячним нагрівачем $40{ }^{\circ} \mathrm{C}$, відмінність між термічним ККД адіабатного та політропного циклів становить: 23 \% (рис. 2, $a$ ) та $12,4 \%$ (рис. 2, б). Для температури повітря за сонячним нагрівачем $90{ }^{\circ} \mathrm{C}$, ця відмінність між ККД становить: $12,3 \%$ (рис. 2, a) та 5,2\% (рис. 2, б).

При температурі паро-повітряної суміші перед турбіною $340{ }^{\circ} \mathrm{C}$ та температурі повітря на виході iз сонячного нагрівача $85{ }^{\circ} \mathrm{C}$ термічний ККД адіабатного цикла досягає 79 \% (рис. 2, б), а електричний $-73,8 \%$ (рис. $3, a$ ). У політропному циклі ці значення менші на 7 та 6,1 \% відповідно.

Розрахунок техніко-економічних показників цикла (ступінь регенерації теплоти, масові витрати робочого тіла та інші) проведено для ГТУ електричною потужністю 10 кВт. 
Із рис. 3, 6 видно, що ступінь регенерації у адіабатному та політропному циклах різко зростає iз збільшенням температури повітря за сонячним нагрівачем. Зростання ступеня регенерації теплоти зменшує відмінність між значеннями термічного ККД у адіабатному та політропному циклах (рис. 2, $а$ та б), оскільки при цьому зменшуються енергетичні втрати. Різниця між значеннями ступеня регенерації теплоти у цих циклах практично на всьому діапазоні температур повітря за сонячним нагрівачем складає 5...7 \%. Ця величина залежить від коефіцієнтів збереження за-

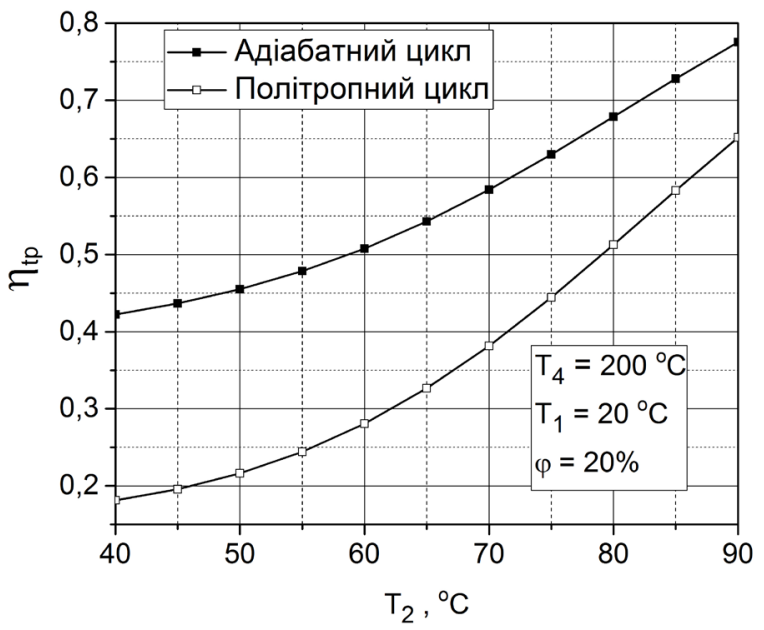

a)

Рис. 2. Залежності термічного ККД $\eta_{\text {tр }}$ у адіабатному та політропному циклах від температури повітря на виході із сонячного нагрівача $T_{2}$ та температури паро-повітряної сумімі перед турбіною $\mathrm{T}_{4}$ : a) $200^{\circ} \mathrm{C} \mathrm{ma} \mathrm{б)} 340{ }^{\circ} \mathrm{C}$.

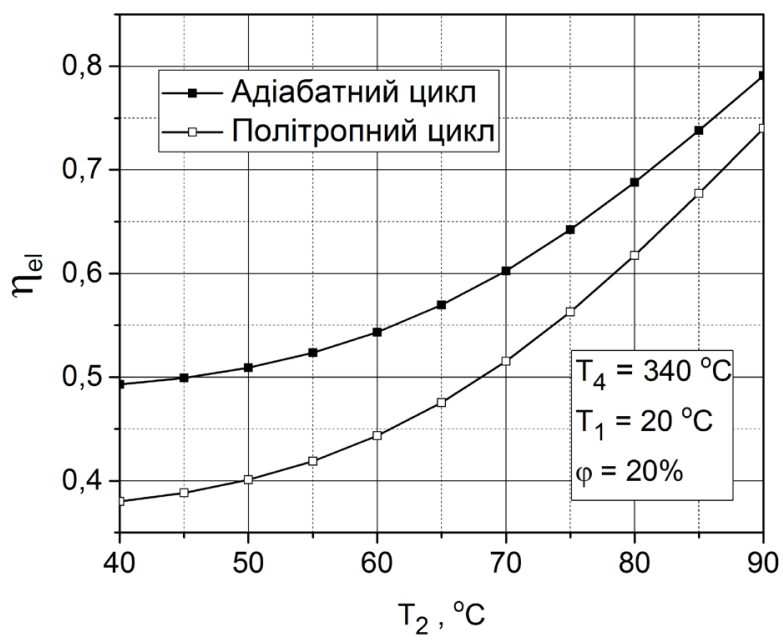

a)

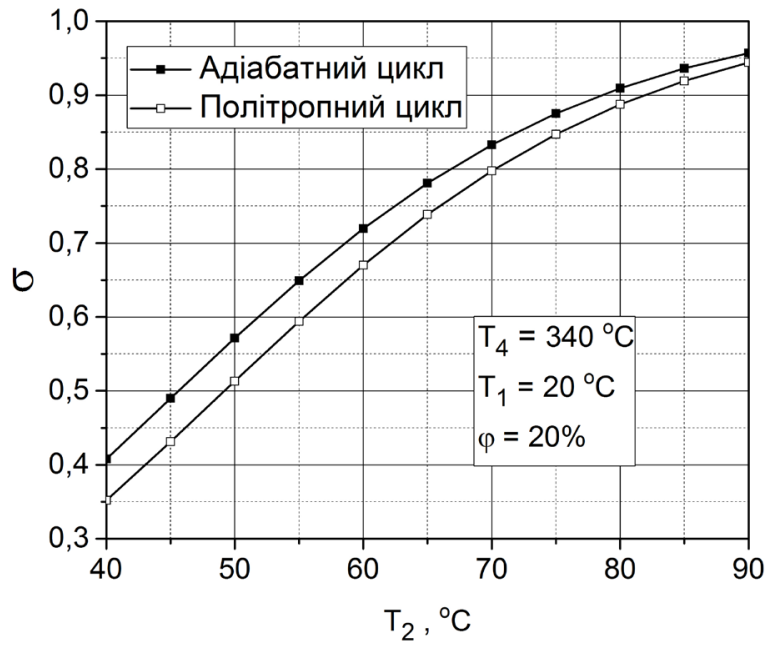

б)

Рис. 3. Залежності техніко-економічних характеристик адіабатного та політропного циклів від температури повітря на виході із сонячного нагрівача $T_{2}$ : а) електричний ККД, б) ступінь регенерації теплоти у апараті Майсоценка. 
Для температури паро-повітряної суміші перед турбіною $340{ }^{\circ} \mathrm{C}$ та температури повітря на виході із сонячного нагрівача $40{ }^{\circ} \mathrm{C}$, необхідні масові витрати повітря у адіабатному циклі складають 38,8 г/с, а у політропному - 48,2 г/с. Для цієї ж самої температури паро-повітряної суміші перед турбіною у випадку, коли температура повітря на виході із сонячного нагрівача становить $90{ }^{\circ} \mathrm{C}$, необхідні масові витрати повітря у адіабатному циклі складають 12,9 г/с, а у політропному $-13,7$ г/с.

На рис. 4, б наведено залежність необхідних масових витрат води у апараті Майсоценка в адіабатному та політропному циклах від температури повітря на виході із сонячного нагрівача. Із цієї залежності видно, що збільшення темпе-

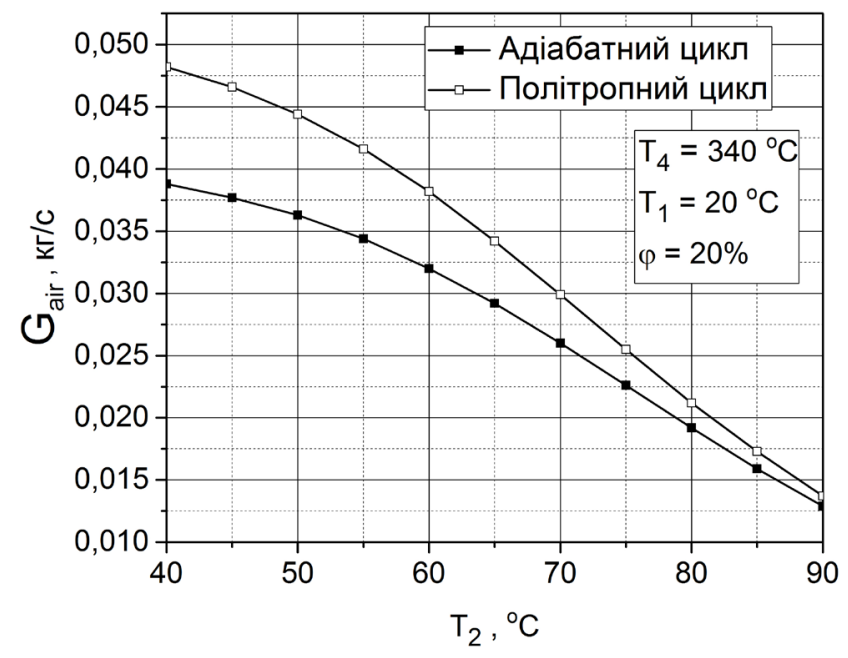

a) ратури повітря за сонячним нагрівачем призводить до лінійного зростання масових витрат води. Для температури паро-повітряної суміші перед турбіною $340{ }^{\circ} \mathrm{C}$ та температури повітря на виході iз сонячного нагрівача $40{ }^{\circ} \mathrm{C}$, необхідні масові витрати води у адіабатному циклі складають 1,7 г/с, а у політропному - 2,2 г/с. Для цієї ж самої температури паро-повітряної суміші перед турбіною у випадку, коли температура повітря на виході із сонячного нагрівача становить $90{ }^{\circ} \mathrm{C}$, необхідні масові витрати води у адіабатному циклі уже складають 14,1 г/с, а у політропному - 15 г/с.

Як показують отримані результати, які наведені на рис. 4, $a$ та $\sigma$-у політропному циклі збільшуються необхідні масові витрат повітря та води відносно масових витрат адіабатного цикла.

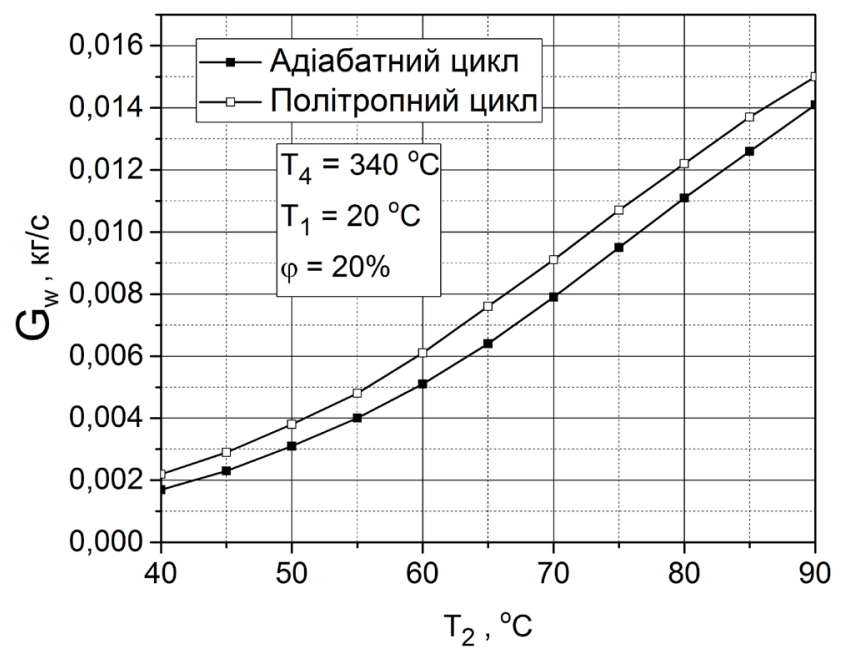

б)

Рис. 4. Залежності масових витрат у адіабатному та політропному цикклах від температури повітря на виході із сонячного нагрівача $T_{2}$ : а) масові витрати повітря газотурбінною установкою, б) масові витрати води в апараті Майсоценка.

\section{Висновки}

Отримано чисельні значення технікоекономічних показників політропного субатмосферного цикла ГТУ з тепломасообмінним апаратом Майсоценка і проведено їх порівняння з технікоекономічними характеристиками адіабатного цикла, які представлені в роботі [2]. На основі отриманих результатів та проведеного аналізу можна зробити такі висновки:

1. Політропна природа термодинамічних процесів зменшує всі техніко-економічні показники цикла.

2. Для температури паро-повітряної суміші перед турбіною $340{ }^{\circ} \mathrm{C}$, термічний ККД політропного цикла зменшується на 12,4 \% та 5,2 \% відносно адіабатного цикла, при зміні температури повітря за сонячним нагрівачем від $40^{\circ} \mathrm{C}$ до $90{ }^{\circ} \mathrm{C}$ відповідно.

3. При температурі паро-повітряної суміші 
перед турбіною $340{ }^{\circ} \mathrm{C}$ та температурі повітря на виході із сонячного нагрівача $85^{\circ} \mathrm{C}$ термічний ККД політропного цикла досягає $72 \%$, а електричний $67,7 \%$.

4. Ступінь регенерації теплоти у політропному циклі незначно зменшується відносно ступеня регенерації теплоти у адіабатному циклі.

5. У політропному циклі необхідні масові витрати повітря та води переважають над масовими витратами адіабатного цикла.

6. Подальша робота дослідження буде зв'язана iз визначення впливу вологості та температури атмосферного повітря на техніко-економічні показники політропного цикла.

\section{ANALYSIS OF POLYTROPIC SUBATMOSPHERIC CYCLE OF GAS TURBINE UNIT WITH MAISOTSENKO HEAT AND MASS EXCHANGER}

\section{Khalatov A.A. ${ }^{1,2}$, Severin S.D. ${ }^{1}$, Kochura Y.P. ${ }^{2}$, Brodetsky P.I. ${ }^{3}$}

${ }^{1}$ Institute of Endineering Thermophysics, National Ukrainian Academy of Sciences, 2a Zhelyabova str., Kiev, 03680, Ukraine

${ }^{2}$ National Technical University of Ukraine "Kiev Polytechnic Institute", 37 Pobedy Avenue, Kiev, 03056, Ukraine

${ }^{3}$ Public Benefit Corporation, Los Angeles, USA

Key words: Brayton's subatmospheric cycle, Maisotsenko's cycle, heat utilisation, polytropic processes, heat transfer.

The thermodynamics analysis of polytropic subatmospheric cycle of gas turbine unit (GTU) with Maisotsenko heat and mass exchanger is executed. Being based on this analysis was obtained technical and economic characteristics of polytropic cycle and conducted their comparing with characteristics of

\section{ЛІТЕРАТУРА}

1. Wilson D. G. The design of high efficiency turbomachinery and gas turbine. - London: MIT Press Cambridge, Massachusetts, 1985. - 534 p.

2. Халатов А.А., Северин С.Д., Бродеиякий П.И., Майсоченко B.C. Субатмосферный обратный цикл Брайтона с регенерацией выходной теплоты по циклу Майсоценко // ISSN 1025-6415 Доповіді Національної академії наук України, 2015, № 1. C. $72-79$.

3. Тарабанов М.Г., Коркин В.Д. , Сергеев В.Ф. Справочное пособие - 1 // «Инженеры по отоплению вентиляции, кондиционированию воздуха, теплоснабжению и строительной теплофизике» (НП «АВОК»), 2004. - 65 c.

adiabatic cycle. It is shown that for the temperature of steam-air mixture at turbine inlet of $340{ }^{\circ} \mathrm{C}$ the thermal efficiency of polytropic cycle decreases in relation to an adiabatic cycle on $12,4 \ldots 5,2 \%$ at the change of air temperature after a sunny heater from 40 to $90^{\circ} \mathrm{C}$. The thermal efficiency of polytropic cycle is reached to 72 per cent.

References 3, tables 1, figures 4 .

1. Wilson D. G. The design of high efficiency turbomachinery and gas turbine. - London: MIT Press Cambridge, Massachusetts, 1985. - 534 p.

2. Khalatov A.A., Severin S.D., Brodetsky P.I., Maisotsenko V.S. Brayton's Subatmospheric Inverted Cycle with Waste Heat Utilization According to the Maisotsenko's Cycle // ISSN 1025-6415 Reports of the National Ukrainian Academy of Sciences, 2015, № 1. - 72-79 p. (Rus.)

3. Tarabanov M.G., Korkin V.D., Sergeev V.F. A Reference Guide - 1 // "Engineers for Heating Ventilation, Air Conditioning, Heat Supply and Building Thermal Physics" (NP "AVOK").- 2004 - 65 p. (Rus.)

Получено 16.11.2015

Received 16.11.2015 